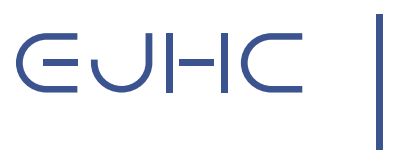

\title{
The Influence of Social Support and Characteristics of the Stigmatisers on Stigmatising Attitudes Towards People With Mental Illness
}

DOI: $10.47368 /$ ejhc. 2021.204 2021, Vol. 2(2) 66-96

CC BY 4.0

\section{Michélle Möhring (D), Natascha Krick, Anika Ditze \\ Qualitative Research Methods and Strategic Communication for Health, Inclusion, and Participation, TU Dortmund University, Germany}

\begin{abstract}
The stigmatisation of people with mental illness has severe negative consequences for affected individuals. As research in the context of exemplification theory (Zillmann \& Brosius, 2000) shows, single-case descriptions of affected individuals (i.e., exemplars) have the potential to either strengthen or reduce stigmatising attitudes towards people with mental illness, in general. We examine the role of depicting social support for exemplars with mental illness (i.e., depression), exemplars' age and sex as well as characteristics of the potential stigmatisers (e.g., sex, relationship status) in generalised stigma-related attitudes towards people with mental illness. A $2 \times 2 \times 2$ online survey experiment with 854 participants was conducted. Univariate ANOVAs yielded main effects and complex interaction patterns of participants' sex and relationship status, as well as combinations of exemplar characteristics. Overall, our results confirm the influence that single-case descriptions can have upon generalised stigma-related attitudes towards people with mental illness. They underline the potential of depicting social support for exemplars with mental illness as well as the consideration of potential stigmatisers' sex and relationship status for (de-)stigmatisation and give starting points for future research in the field of health and anti-stigma-communication.
\end{abstract}

\section{Keywords}

Stigmatisation, exemplification, mental health, social support, relationship status, sociodemographic factors. 
Worldwide, approximately 970 million people are affected by mental illnesses (GBD 2015 Disease and Injury Incidence and Prevalence Collaborators, 2016). Depression, anxiety, and bipolar disorder are among the most common, with depression having the highest prevalence (264 million affected). While depression in general can have severe consequences for a person's health, diagnosed persons not only have to deal with their health problems but also endure the stigma that comes with being labelled as depressive (WHO, 2020). The combination of symptoms of depression with society's stigmatising attitudes towards depression results in people with depression exhibiting various maladaptive behaviours, such as a lower likelihood of asking others for help. These behaviours and the general public stigmatisation of mental illnesses such as depression prevent diagnosed individuals from, for example, accessing work, education, and health services (e.g., Hebl \& Kleck, 2000).

Stigmatisation manifests not only at the level of attitudes (in the sense of prejudices and stereotypes) but also at the level of behavioural intentions towards stigmatised individuals or groups, and it can also predict discriminatory behaviour (theory of planned behaviour: Ajzen, 1985). In order to change people's attitudes towards marginalised groups in general and to reduce stigmatising attitudes, such as prejudices and stereotypes, in particular, contact with potentially stigmatised individuals has been identified as an influential intervention strategy (contact hypothesis: Allport, 1954). While Allport (1954) postulates that face-to-face contact has the strongest impact on stigma, studies have shown that media-mediated contact, for instance being exposed to single-case descriptions of people with mental illness, can have similar destigmatising effects (e.g., Clement et al., 2013; Morgan et al., 2009; Peter et al., 2014; Riles, 2020; Shanahan \& Morgan, 1999; Zillmann \& Brosius, 2000). In the media, single-case descriptions (i.e., exemplars) are often used as a stylistic device to illustrate and personalise abstract or complex issues or to increase the public's attention (Krämer \& Peter, 2020; Krämer, 2015). This makes them a familiar and low-threshold method to decrease stigmatising attitudes towards marginalised individuals and groups.

Based on the theoretical framework of exemplification theory (Zillmann \& Brosius, 2000; Zillmann, 2008), the present study was designed to investigate the influence that different, potentially stigma-relevant characteristics (i.e., sex, age, and social support) of exemplars with mental illness have on the potential stigmatisers' generalised stigma-related attitudes towards people with mental illness. Furthermore, the influence of stigma-relevant characteristics of the potential stigmatisers (i.e., sex or relationship status) was investigated.

\section{The Role of Exemplification for the (De-)Stigmatisation of Mental IIIness}

Because exemplars are powerful in shaping the public's attitudes they play a pivotal role in the context of (de-)stigmatising of marginalised individuals and groups, such as people with mental illness (Clement et al., 2013; Morgan et al., 2009; Peter et al., 2014; Zillmann \& Brosius, 2000). Exemplification theory (Zillmann \& Brosius, 2000) postulates on the basis of assumptions regarding quantification and representativeness heuristics that the exemplification of a phenomenon (e.g., mental illness) can lead to a modification or change of attitudes and beliefs about the phenomenon in general (e.g., generalised attitudes towards people with mental illness). Research in the field of exemplification theory further examines the conditions under which 
attitudes and beliefs towards an exemplified phenomenon change (Zillmann, 2008; Zillmann \& Brosius, 2000) as they can be influenced both positively and negatively by exemplars (e.g., Wang, 2020).

At the level of the potential stigmatisers, Mouzas et al. (2008) found, for example, that sociodemographic factors (e.g., sex, social status, family status) influence the public's opinion about mental illness: In their study they found in a Greek sample that a male sex, a low social status as well as a divorced status, among other factors, facilitate negative attitudes of the potential stigmatisers towards the social discrimination and social restriction of people with mental illness.

Furthermore, at the level of exemplars, research has shown that the type of presentation (in terms of framing as well as the exemplars' characteristics) influences (de-)stigmatising effects in the context of exemplification (e.g., Baer et al., 2015; Frankham, 2019; Gwarjanski \& Parrott, 2018; McGinty et al., 2014; Wahl, 1996; Wright et al., 2012). For example, Gwarjanski \& Parrott (2018) found that the media holds stigma frames (i.e., the communication of stereotypes) as well as stigma-challenge frames (i.e., the contradiction of stereotypes) about schizophrenia. While stigma frames linking schizophrenia to violence and criminal behaviour negatively affect readers' stigmatising responses towards mental illness, stigma-challenge frames positively affect the readers' likelihood to disclose their personal experience of mental illness.

Journalists often use exemplars of marginalised individuals or groups such as people with mental illness to personalise their content or to focus attention (e.g., Wang, 2020). Therefore, the media holds considerable potential for (de-)stigmatisation (Shanahan \& Morgan, 1999; Vyncke \& van Gorp, 2018). However, it still mostly portrays mental illness in a negative fashion and maintains the public's overall negative view on mental illness through the overuse and generalisation of labels, such as depression, to the facilitation of stereotypes (e.g., violent and suicidal: Wang, 2020), and negative framing. In addition, it continues to use pejorative language in association with mental illness (e.g., Baer et al., 2015; Gwarjanski \& Parrott, 2018; McGinty et al., 2014; Frankham, 2019).

Beyond the overall stigmatisation of mental illness, the media fosters a gendered perception of mental illness, associating some mental disorders, such as depression, more with women and other disorders, such as substance abuse, with men, which can be explained by the cause of the underlying illness (van Driel et al., 2018). Depression and anxiety are viewed as emotiondependent and are thus more commonly associated with women, while substance abuse results from risky behaviours which are mostly associated with men (van Driel et al., 2018). Moreover, Wirth and Bodenhaus (2009) found that disorders that are typically associated with the gender of the affected person (gender-typical disorders) result in more stigmatising attitudes and negative emotions being displayed towards the affected person than gender-atypical disorders do.

Since exemplars' (binary, biological) sex (e.g., Dolphin \& Hennessy, 2016; Thibodeau et al., 2015) as well as exemplars' age (e.g., Crisp et al., 2005; Griffiths et al., 2008; Hahm et al., 2020; Mackenzie et al., 2019) have been identified as influential factors for stigmatisation and destigmatisation through exemplification in different contexts, we examined the role of these two factors for the (de-)stigmatisation of people with mental illness in general and specifically people with depression. In line with Wirth and Bodenhaus (2009), we hypothesise that female exemplars with depression evoke more negative generalised stigma-related attitudes compared to male 
exemplars, as depression is generally perceived as a more female-typical disorder (van Driel et al., 2018):

Hypothesis 1: Female exemplars with depression evoke more negative generalised stigmarelated attitudes towards people with mental illness compared to male exemplars.

Mouzas et al. (2008) found, for example, that older people generally have more negative stigmatising attitudes towards people with mental illness compared to younger people. Based on the assumptions of social comparison theory (Festinger, 1954) and social identity theory (Tajfel \& Turner, 1986), we hypothesise that the age of a depicted exemplar with depression affects readers' generalised stigma-related attitudes towards people with depression. Specifically, we hypothesise that in-group/out-group distinctions occur that influence readers' attitudes towards the potentially stigmatised group to which the depicted exemplar belongs (e.g., Chung \& Slater, 2013). Here, the depiction of a young exemplar with depression favours stigma-reducing in-group comparisons among younger readers and stigma-increasing out-group comparisons among older readers:

Hypothesis 2: Young exemplars with depression evoke more positive generalised stigmarelated attitudes towards people with mental illness among younger readers compared to older readers.

\section{The Role of Social Support for the (De-)Stigmatisation of Mental Illness}

In addition to exemplars' sex and age, we consider exemplars' social support as a potentially stigma-relevant exemplar feature in the context of (de-)stigmatisation of people with mental illness. For people with mental health issues, getting the (social) care needed often poses a problem, since those who are not yet diagnosed with a mental illness tend to avoid seeking help as a result of the stigmatisation that comes with being labelled as mentally ill (e.g., Henderson et al., 2013). The label (i.e., the diagnosis) that allows people to get the help they need also singles them out and causes stigmatisation, creating a so-called 'labelling paradox' (Perry, 2011). Due to a fear of stigmatisation, individuals with mental health problems tend to refrain from social contact and isolate themselves, resulting in a lack of (social) support and (medical) care (e.g., Park \& Park, 2014).

To enable a person with mental health issues to cope with (daily) life, especially during acute phases of illness, they need support from their social environment as well as appropriate medical care (Barney et al., 2006). An article on major depression that surveyed affected people found that social support (if available) mostly came from their families (Lasalvia et al., 2015). As research in this field has shown, stigmatisation not only affects the people with a mental illness themselves but also their entire families. This family stigma occurs when, for example, others have negative attitudes towards the family because of their unusual characteristics, when the appearance of the family is perceived as different from general social norms or when others believe that the family members are directly or indirectly 'contaminated' by the affected family member (Park \& Park, 2014). In the context of (de-) stigmatisation through exemplification, the following question arises: In which ways can a depiction of an exemplar with depression receiving social support from family and friends influence generalised stigmatising or destigmatising attitudes towards people with mental illness? 
As mentioned previously, a high degree of social support is vital to reduce the adverse effects of stigmatisation on people with mental illness (e.g., Mueller et al., 2006). Social support can be grouped into four types: (1) Emotional support, which includes but is not limited to a person feeling valued; (2) informational support, which refers to a person obtaining the information necessary to help them overcome critical situations; (3) tangible support, which involves forms of financial aid and help with specific tasks (e.g., receiving care and assistance with transportation); and (4) companionship support, which refers to belonging to a group and meeting with other people (Bambina, 2007; Yao et al., 2015). In a more general way, support can be separated into structural and functional support. Structural support is the social network an individual engages with and the rate at which the individual has contact with their network, and functional support determines which services are rendered because of an individual's relationships (Taylor, 2011).

Therefore, in this paper, we examine what influence depicting a student with depression (i.e., exemplar) receiving social support from family and friends (i.e., structural support) has on readers' stigma-related attitudes towards people with depression in general. Since social support is considered a norm within our society (e.g., Reimer et al., 2008), we hypothesise that exemplars who are depicted as receiving structural support from family and friends evoke less stigma-related attitudes compared to exemplars who lack social support (and are therefore not able to pursue their studies):

Hypothesis 3: Exemplars with depression who receive social support evoke more positive generalised stigma-related attitudes towards people with mental illness compared to exemplars who do not receive social support.

\section{The Role of Characteristics of the Stigmatisers on the (De-)Stigmatisation of Mental Illness}

In addition to the aforementioned exemplars' characteristics, in the context of stigmatisation and exemplification characteristics of the potential stigmatisers (in this case: readers of an exemplar with depression) influence the (de-)stigmatising exemplification effects. Many studies point out that stigmatisation must be considered against the background of the stigmatisers' characteristics in order to develop more targeted intervention strategies for destigmatisation based on the findings (e.g., Abdullah \& Brown, 2019; Hahm et al., 2020; Mackenzie et al., 2019). For example, Abdullah \& Brown (2019) analysed mental illness stigma among Black Americans. Some of their results were very specific among Black Americans compared to other racial groups so that the authors argue in support of the differentiation of mental illness stigma among different racial groups. Hahm et al. (2020) also examined the stigma of mental illness and found an influence of sociodemographic variables such as potential stigmatisers' age. They found that older age was associated with more negative stigma-related attitudes towards mental illness.

Findings of Mackenzie et al. (2019) as well as other researchers (e.g., Anderson et al., 2015; Batterham et al., 2013; Corrigan et al., 2003; Griffiths et al., 2008; Spence et al., 2015; Yap et al., 2013) suggest that, overall, women tend to exhibit more positive stigmatising attitudes than men. These effects of the potential stigmatisers' gender held true within different stigmatised conditions, such as mental illness or more specifically depression and suicide (e.g., Anderson et al., 2015; Mackenzie et al., 2019), as well as in different age groups: Dolphin and Hennessey (2016) were 
able to validate these results in adolescents, for example. These findings underline the substantial influence that the potential stigmatisers' gender can have on the stigmatisation of individuals and groups. In line with previous research, we thus test the following assumption in the present study:

Hypothesis 4: Women report more positive generalised stigma-related attitudes towards people with mental illness than men after being exposed to an exemplar with depression.

While a direct effect of the potential stigmatisers' gender has been found in several studies, Hastall and colleagues (2016) identified a less researched characteristic as potentially influential for (de-)stigmatising effects: the stigmatisers' relationship status. In the context of the stigmatisation of people with disabilities, the authors found that people in a relationship reported more positive stigma-related attitudes towards people with a disability than singles. The impact of being in a relationship has also been identified in other contexts with different results: Bryant et al. (2012) found a link between the participants' relationship status in their study and their views on ageing, with people in a relationship having more positive attitudes towards ageing as well as better mental health than singles. Pettijohn et al. (2010) found that students who were in a relationship had higher self-esteem and a better body image than singles. Lucier-Greer and AdlerBaeder (2011), however, observed that individuals showed stronger egalitarian attitudes after divorce than before divorce. Since the direction of the influence of potential stigmatisers' relationship status on stigma-related attitudes is not yet clear, relationship status was considered as a potentially stigma-relevant exploratory factor in the present study. This led us to the following additional research question:

Research Question: How does the potential stigmatisers' relationship status influence generalised stigmatising attitudes towards people with mental illness after being exposed to an exemplar with depression?

\section{Method}

\section{Design and Procedure}

We conducted a $2 \times 2 \times 2$ online survey experiment, in which participants read a single-case description (i.e., an exemplar) of a student with depression. The exemplar was manipulated in terms of the student's binary, biological sex (male vs. female), age (young adult vs. old age), and whether or not they received social support (social support vs. no social support). The version describing a student receiving social support from family and friends ends with the student being motivated to continue his/her studies. The other version, describing a student without any social support, ends with the student considering dropping out of university.

Participants were recruited via an email written to all existing student associations across 34 universities in Germany. The survey link was also shared in 54 Facebook groups associated with these universities and on several universities' survey pages. Since the whole study was conducted in Germany, the survey and all relevant materials were in German.

The required sample size $N=787$ was calculated with $\mathrm{G}^{*}$ Power (ANOVA of the a priori type) with an expected effect size of $f=.10$, an Alpha error of $\alpha=.05$, and a Beta error of $\beta=.20$. The required sample size was achieved within 2 months. A total of $N=1416$ students responded, of 
which $n=854$ participants completed the online questionnaire in full. All students were randomly assigned to one of the eight experimental conditions. Participants were asked to fill out a survey that began with questions about the participants' socio-demographic profile before presenting the exemplar. Next, stigma-related attitudes were assessed. Finally, participants were asked about their current relationship status (single item) at the end of the survey to prevent early dropout due to negative associations, in the event that people might perceive this question as too personal.

\section{Stimulus Material and Manipulation Check}

To examine the influence of single-case descriptions on stigmatising attitudes, an exemplar was created that highlighted the symptoms of depression as described by the diagnostic manuals DSMV and ICD-10 (APA, 2013; WHO, 2004). While the symptoms of depression were used to describe the person's behaviour, a label for these behaviours was omitted to circumvent the labelling effect. The survey thus used the general label of 'mental illness'. We chose to use symptoms of depression, since they are generally well known, so that participants could empathise more easily with the person portrayed (e.g., Bahlmann et al., 2015; DGPPN, 2020). An example of the description of depressive symptoms from one of our stimulus versions is 'Die 24-Jährige Laura fühlt seit einiger Zeit eine innere Leere. Im Studium fehlt ihr die Kraft und Motivation, sich so anzustrengen, wie sie es vor einem Jahr konnte [24-year-old Laura has been feeling hollow for some time. She lacks the energy and motivation to try as hard as she used to be able to a year ago].'

To examine the influence of social support on an affected individual, students are either depicted as receiving help from friends and family, and subsequently resume their studies, or as having a lack of social support, leading to their exmatriculation. Therefore, the social support manipulation was the most significant, locating the exemplar either within a socially supportive environment or a non-supportive environment. The three manipulations (sex, age, and social support) resulted in eight different versions of the stimulus (see appendix).

A manipulation check was conducted to confirm the exemplar manipulations. This was achieved by having a pilot group of $N=45$ participants ( $M=32$ years; $S D=13.9 ; 84.8 \%$ female) fill out a short questionnaire containing four of the eight versions of the stimulus material. The participants each read the presented stimuli and were asked what kind of manipulations occurred within the text in a single choice format. The manipulation check confirmed the successful manipulations with a Krippendorff's alpha of 1.0 for exemplars' sex, a Krippendorff's alpha of .97 for exemplars' age, and a Krippendorff's alpha of .94 for exemplars' social support.

\section{Sample}

The sample consisted of 854 students attending different universities throughout Germany. The average age of participants was $24.4(S D=4.5 ; 67.6 \%$ female), and $55.3 \%$ of the participants stated they were currently in a relationship. Most of the students studied natural sciences (37.4\%), whereas around a quarter studied social sciences (23.8\%). Out of all of the participants, $14.5 \%$ stated they were taking a technical course; $5.2 \%$ were taking business studies; $4 \%$ were studying medicine; and $0.9 \%$ were studying law; $14.3 \%$ selected 'other academic courses'. 
Table 1. Means, Standard Deviations, and Intercorrelations of all Dependent Measures

\begin{tabular}{llcccc}
\hline & & $M$ & $S D$ & 2. & 3. \\
\hline 1. & Integration (CAMI) & 3.96 & 0.58 & $.57^{* *}$ & $-.48^{* *}$ \\
2. & Benevolence (CAMI) & 4.37 & 0.56 & - & $-.57^{* *}$ \\
3. & Social restrictiveness (CAMI) & 1.57 & 0.58 & & - \\
\hline
\end{tabular}

Note. CAMI $=$ Community Attitudes towards Mental Illness. ${ }^{* *} p<.01$ (2-tailed).

\section{Measures}

To assess participants' stigma-related attitudes towards people with mental illness, three subscales of the Community Attitudes towards the Mentally Ill scale by Dear and Taylor (1979) were used. In the German version of the scale by Angermeyer et al. (2003), items were reassigned to different subscales. The subscale mental health ideology was excluded because we did not want to collect data on people's attitudes towards the living situation and neighbourhood of people with mental illness. The included subscales were integration, which consisted of nine items (Cronbach's alpha =.79; e.g., 'The best therapy for many mental patients is being part of a normal community'), benevolence, which consisted of eight items (Cronbach's alpha = .82; e.g., 'More tax money should be spent on the care and treatment of the mentally ill'), and social restrictiveness, which comprised eight items (Cronbach's alpha $=.80$; e.g., 'Mental patients need the same kind of control and discipline as a young child.') Participants rated their agreement with the statements according to a 5-point Likert scale from 1 (completely disagree) to 5 (completely agree). High values in the subscales integration and benevolence thus indicate a less stigmatising or more positive attitude towards people with mental illness, while high values in the subscale social restrictiveness indicate a more stigmatising or negative attitude towards people with mental illness.

See Table 1 for an overview of means, standard deviations, and intercorrelations of the included subscales.

\section{Results}

Univariate ANOVAs were conducted with the three experimental manipulations (sex, age, social support) as well as participants' sex, age (median-split), and relationship status as categorical factors. To ensure sufficient cell sizes with $n>30$ respondents per cell, the model was limited to main effects, two-way interactions, and three-way interactions. The significance of differences between the estimated marginal means was determined through Sidak-corrected ${ }^{1}$ simple effect post-hoc tests $(p<.05)$. Below, results are reported following the relevant hypotheses and research question, and interaction effects are reported when the post-hoc analyses revealed significant differences between the estimated marginal means $(p<.05)$.

\section{Influence of the Exemplars' Sex, Age, and Social Support on Stigma-Related Attitudes Towards Mental IIIness}

We hypothesised the main effects of the exemplars' sex, age, and social support on the readers' generalised stigma-related attitudes towards people with mental illness. Contrary to our assumptions, the analysis did not reveal any main effect of the three exemplar features on 
integration, benevolence, and social restrictiveness; therefore hypotheses 1-3 have to be rejected (see tables 2 and 3 for an overview of the statistical parameters and the estimated marginal means). Instead, we found complex interaction patterns for exemplar feature combinations with the readers' relationship status regarding integration and benevolence.

A three-way interaction of exemplars' age $\times$ exemplars' social support $\times$ participants' relationship status emerged for integration, $F(1,797)=3.988, p=.046, \eta^{2}=.005$. As Figure 1 shows, participants who are single reported more positive stigma-related attitudes towards the integration of people with mental illness when they were exposed to young exemplars with depression who received social support $(M=4.0, S E=.06)$; but this was only the case when compared to those participants who are single and were exposed to young exemplars without social support $(M=3.86, S E=.06, p=.042)$. However, this difference in attitudes towards the integration of people with mental illness did not occur with participants in a relationship or after being exposed to older exemplars.

Furthermore, analysis yielded a three-way interaction of exemplars' sex $\times$ exemplars' social support $\times$ participants' relationship status for benevolence, $F(1,796)=6.424, p=.011, \eta^{2}=.007$. The Sidak-corrected post-hoc analysis of the estimated marginal means showed that participants who are single reported more positive stigma-related attitudes (i.e., more benevolence) when they were exposed to male exemplars who were described as receiving social support $(M=4.45$, $S E=.06)$ compared to participants who are single and were exposed to female exemplars who were described as receiving social support $(M=4.25, S E=.06, p=.023$; Figure 2). However, this difference in benevolence towards people with mental illness according to the exemplars' sex did not emerge for participants in a relationship and also did not depend on the depiction of a lack of social support for the exemplar.

Table 2. Main Effects of Exemplars' Sex, Age and Social Support on Stigma-Related Attitude Dimensions

\begin{tabular}{lcccc}
\hline & $F$ & $d f\left(d f_{\text {error }}\right)$ & $\eta^{2}$ & $p$ \\
\hline Benevolence & & & & \\
\hline Exemplars' sex & 2.074 & $1(796)$ & .002 & .150 \\
Exemplars' age & 1.293 & $1(796)$ & .001 & .256 \\
Exemplars' social support & 0.239 & $1(796)$ & $<.001$ & .625 \\
\hline Integration & & & \\
\hline Exemplars' sex & 0.486 & $1(797)$ & $<.001$ & .486 \\
Exemplars' age & 0.028 & $1(797)$ & $<.001$ & .867 \\
Exemplars' social support & 0.371 & $1(797)$ & $<.001$ & .542 \\
\hline Social restrictiveness & & & \\
\hline Exemplars' sex & 1.267 & $1(795)$ & .001 & .261 \\
Exemplars' age & 3.078 & $1(795)$ & .004 & .080 \\
Exemplars' social support & $<.001$ & $1(795)$ & $<.001$ & .998 \\
\hline
\end{tabular}


Table 3. Estimated Marginal Means of Exemplars' Sex, Age and Social Support on Stigma-Related Attitude Dimensions

\begin{tabular}{|c|c|c|c|c|c|c|c|c|c|}
\hline & \multicolumn{4}{|c|}{ Female exemplars } & \multicolumn{4}{|c|}{ Male exemplars } & \multirow[t]{3}{*}{$p$} \\
\hline & \multirow[t]{2}{*}{$M$} & \multirow[t]{2}{*}{$S E$} & \multicolumn{2}{|c|}{$95 \% \mathrm{Cl}$} & \multirow[t]{2}{*}{$M$} & \multirow[t]{2}{*}{$S E$} & \multicolumn{2}{|c|}{$95 \% \mathrm{Cl}$} & \\
\hline & & & $L L$ & $U L$ & & & $L L$ & $U L$ & \\
\hline Benevolence & 4.30 & 0.03 & 4.23 & 4.35 & 4.36 & 0.03 & 4.29 & 4.42 & .150 \\
\hline Integration & 3.93 & 0.03 & 3.86 & 3.99 & 3.96 & 0.03 & 3.89 & 4.02 & .486 \\
\hline \multirow[t]{4}{*}{ Social restrictiveness } & 1.61 & 0.03 & 1.56 & 1.67 & 1.57 & 0.03 & 1.51 & 1.62 & .261 \\
\hline & \multicolumn{4}{|c|}{ Young exemplars } & \multicolumn{4}{|c|}{ Older exemplars } & $p$ \\
\hline & \multirow[t]{2}{*}{$M$} & $S E$ & \multicolumn{2}{|c|}{$95 \% \mathrm{Cl}$} & \multirow[t]{2}{*}{$M$} & $S E$ & \multicolumn{2}{|c|}{$95 \% \mathrm{Cl}$} & \\
\hline & & & $L L$ & $U L$ & & & $L L$ & $U L$ & \\
\hline Benevolence & 4.35 & 0.03 & 4.29 & 4.41 & 4.30 & 0.03 & 4.24 & 4.36 & .256 \\
\hline Integration & 3.95 & 0.03 & 3.88 & 4.01 & 3.94 & 0.03 & 3.87 & 4.00 & .867 \\
\hline \multirow[t]{4}{*}{ Social restrictiveness } & 1.55 & 0.03 & 1.50 & 1.57 & 1.63 & 0.03 & 1.61 & 1.68 & .080 \\
\hline & \multicolumn{4}{|c|}{ Exemplars with social support } & \multicolumn{4}{|c|}{ Exemplars without social support } & $p$ \\
\hline & \multirow[t]{2}{*}{$M$} & $S E$ & \multicolumn{2}{|c|}{$95 \% \mathrm{Cl}$} & $M$ & $S E$ & \multicolumn{2}{|c|}{$95 \% \mathrm{Cl}$} & \\
\hline & & & $L L$ & $U L$ & & & $L L$ & $U L$ & \\
\hline Benevolence & 4.31 & 0.03 & 4.25 & 4.37 & 4.34 & 0.03 & 4.27 & 4.40 & .625 \\
\hline Integration & 3.96 & 0.03 & 3.89 & 4.02 & 3.93 & 0.03 & 3.86 & 3.99 & .542 \\
\hline Social restrictiveness & 1.59 & 0.03 & 1.53 & 1.65 & 1.59 & 0.03 & 1.53 & 1.65 & .998 \\
\hline
\end{tabular}

5

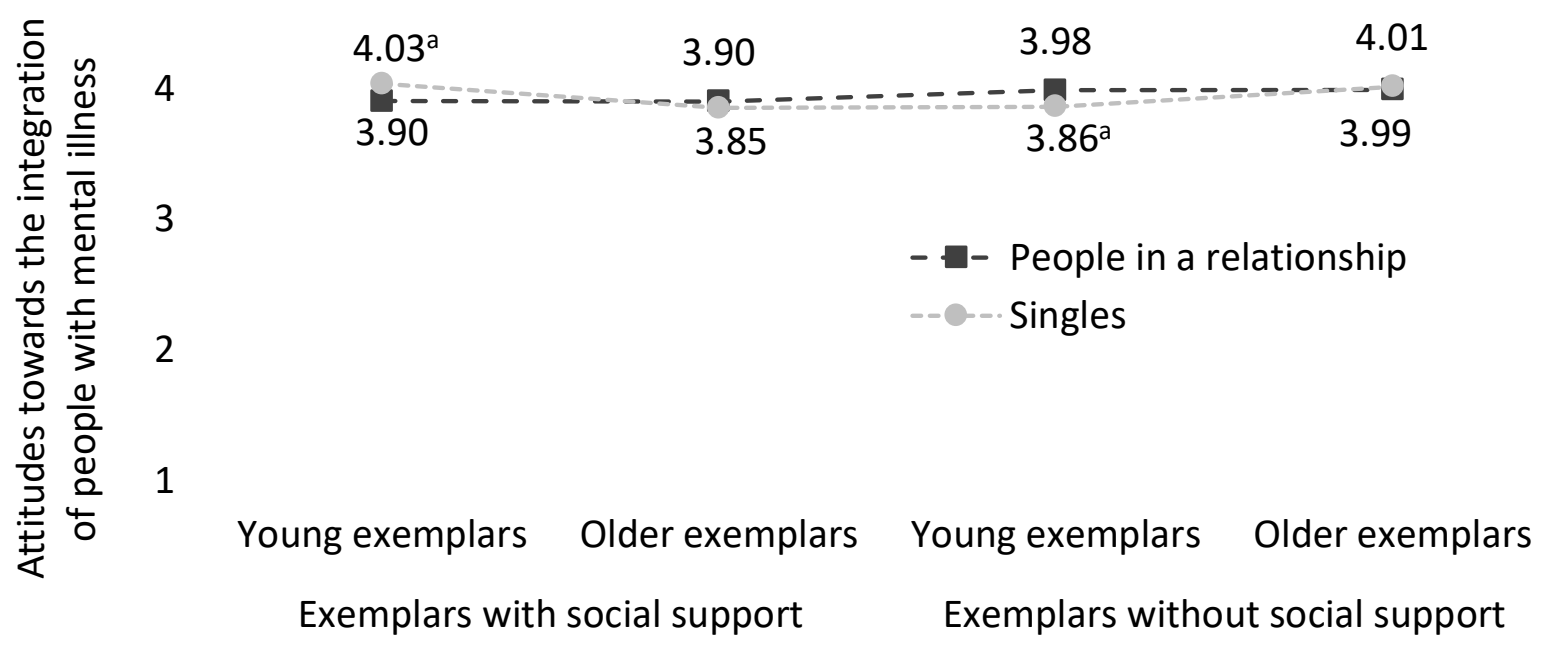

Figure 1. Estimated Marginal Means for the Exemplars' Age $\times$ Exemplars' Social Support $\times$ Participants' Relationship Status Three-Way-Interaction on Integration. Note. Means sharing the same small letter differ at the level of $p<.05$ (Sidak-corrected simple effect post-hoc comparisons). 


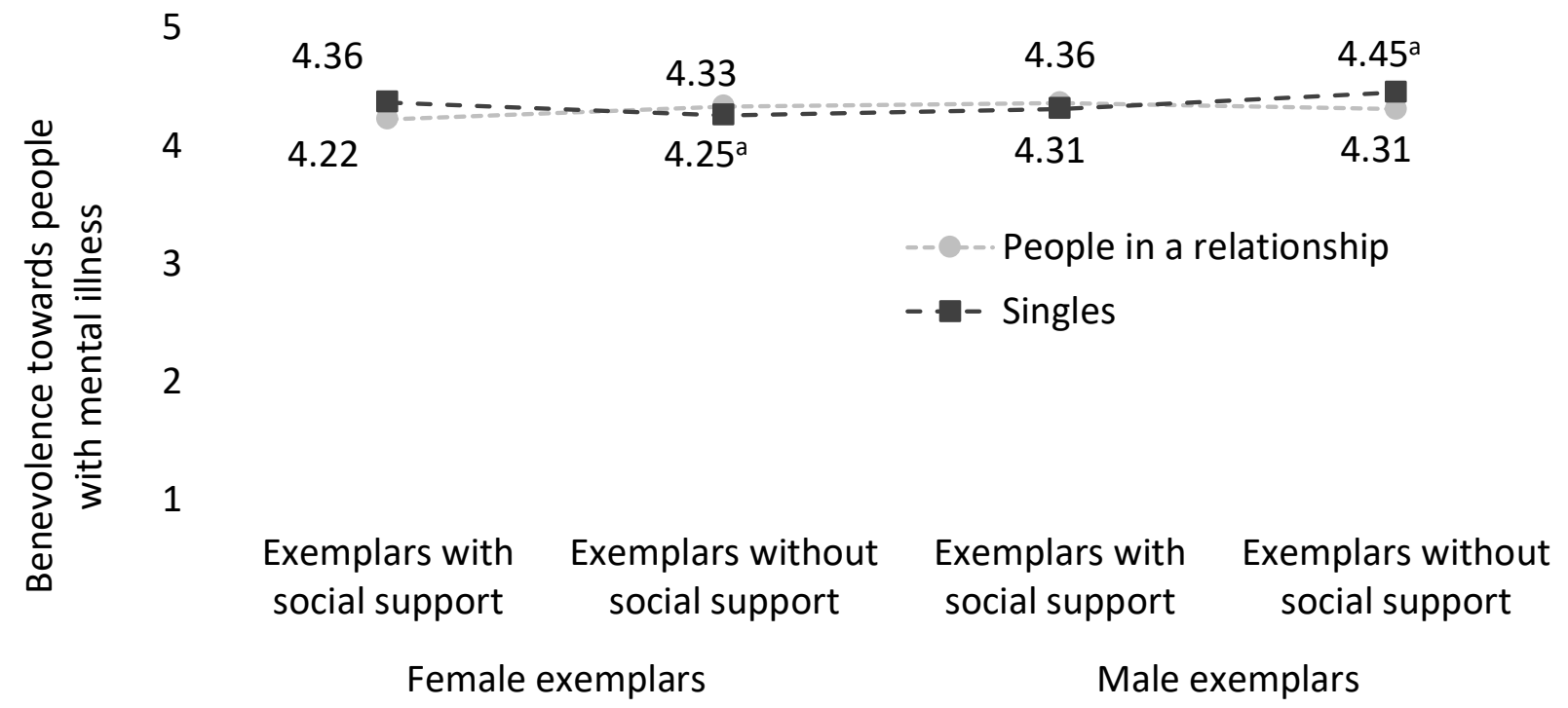

Figure 2. Estimated Marginal Means for the Three-Way-Interaction of Exemplars'

Sex $\times$ Exemplars' Social Support $\times$ Participants' Relationship Status on Benevolence. Note. Means sharing the same small letter differ at the level of $p<.05$ (Sidak-corrected simple effect post-hoc comparisons).
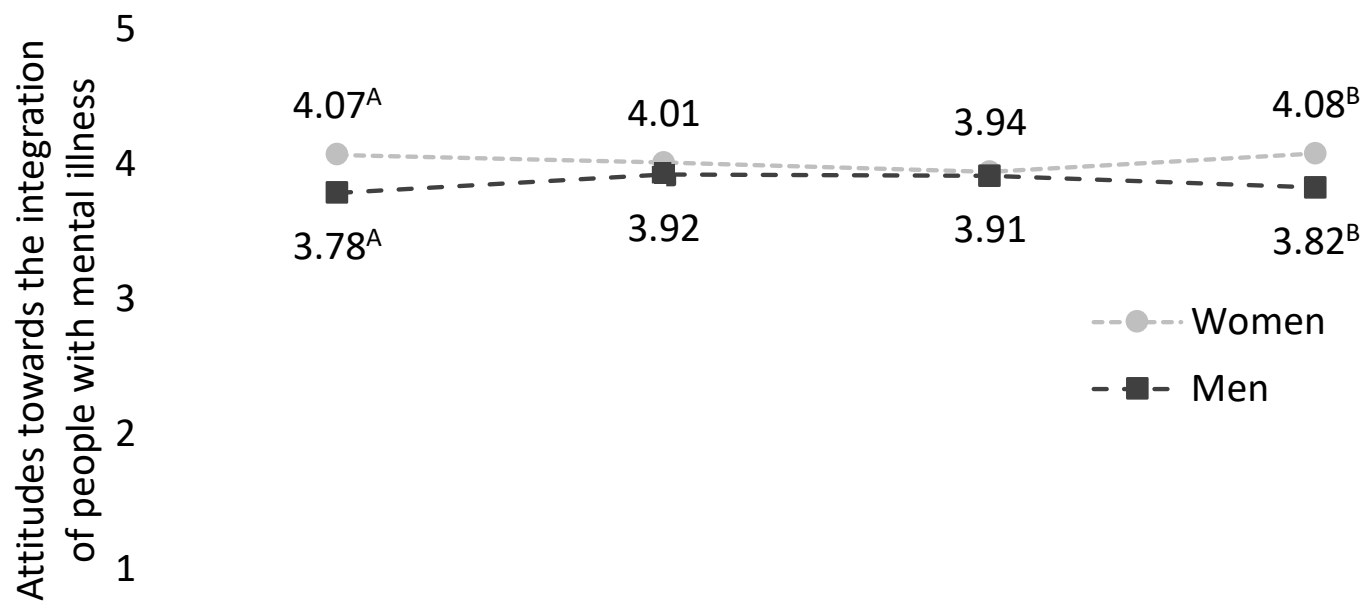

Female exemplars Male exemplars Female exemplars Male exemplars Young exemplars Older exemplars

Figure 3. Estimated Marginal Means for the Three-Way-Interaction of Participants' Sex $\times$ Exemplars' Sex $\times$ Exemplars' Age on Integration.

Note. Means sharing the same capital letter differ at the level of $p<.01$ (Sidak-corrected simple effect post-hoc comparisons). 


\section{Influence of the Participants' Sex and Relationship Status on Stigma-Related Attitudes Towards Mental IIIness}

We hypothesised the main effects of the participants' sex on generalised stigma-related attitudes towards people with mental illness (Hypothesis 4). In line with our assumption, the analysis yielded the main effects of participants' sex on benevolence, $F(1,796)=26.697, p<.001$, $\eta^{2}=.031$, on integration, $F(1,797)=12.604, p<.001, \eta^{2}=.015$, and on social restrictiveness, $F(1,795)=2.434, p<.01, \eta^{2}=.011$. Table 4 gives an overview of the Sidak-corrected estimated marginal means for the three dependent variables. Overall, these findings imply that women are more benevolent towards people with mental illness, show more positive attitudes towards the integration of people with mental illness, and are less socially restrictive against people with mental illness compared to men, which, in turn, means they are less stigmatising compared to men across all three stigma-relevant attitude dimensions. Thus, we found support for our fourth hypothesis.

Furthermore, a three-way interaction of participants' sex $\times$ exemplars' sex $\times$ exemplars' age emerged for integration, $F(1,797)=5.325, p=.021, \eta^{2}=.006$. The Sidak-corrected estimated marginal means (Figure 4) showed that women only have a more positive attitude towards the integration of people with mental illness than men when they have been exposed to either young female exemplars or old male exemplars. Thus, the main effect of the participants' sex on the stigma-related attitude dimension integration cannot be globally interpreted.

In addition to the hypotheses, we investigated the role of participants' relationship status in generalised stigma-related attitudes towards people with mental illness after exposure to exemplars with depression. The analyses revealed a main effect of participants' relationship status on the stigma-related attitude dimension social restrictiveness, as well as several rather complex interaction patterns of participants' relationship status with a combination of exemplar characteristics regarding the stigma-related attitude dimensions integration and benevolence (Table 5).

The post-hoc analyses of the estimated marginal means show that participants in a relationship reported more negative stigma-related attitudes towards people with mental illness than participants who are single: After being exposed to exemplars with depression, participants in a relationship are more likely to think that people with mental illness should be socially restricted $(M=1.65 ; S E=.039)$ than participants who are single $(M=1.53 ; S E=.03 ; p=.004)$.

Table 4. Estimated Marginal Means of Participants' Sex on Stigma-related Attitude Dimensions

\begin{tabular}{|c|c|c|c|c|c|c|c|c|}
\hline & \multicolumn{4}{|c|}{ Women } & \multicolumn{4}{|c|}{ Men } \\
\hline & \multirow[t]{2}{*}{$M$} & \multirow[t]{2}{*}{$S E$} & \multicolumn{2}{|c|}{$95 \% \mathrm{Cl}^{*}$} & \multirow[t]{2}{*}{$M$} & \multirow[t]{2}{*}{$S E$} & \multicolumn{2}{|c|}{$95 \% \mathrm{Cl}^{*}$} \\
\hline & & & $L L$ & $U L$ & & & $L L$ & $U L$ \\
\hline Benevolence & 4.44 & 0.03 & 4.39 & 4.49 & 4.21 & 0.04 & 4.14 & 4.28 \\
\hline Integration & 4.02 & 0.03 & 3.97 & 4.08 & 3.86 & 0.04 & 3.79 & 3.93 \\
\hline Social restrictiveness & 1.53 & 0.02 & 1.48 & 1.57 & 1.65 & 0.03 & 1.59 & 1.72 \\
\hline
\end{tabular}

Note. ${ }^{*} p<.05$ (Sidak-corrected simple effect post-hoc comparisons). 
Table 5. Main Effect and Higher-Order Interactions with Participants' Relationship Status

\begin{tabular}{lcccc}
\hline & $F$ & $d f\left(d f_{\text {error }}\right)$ & $\eta^{2}$ & $p$ \\
\hline $\begin{array}{l}\text { Main effect on social restrictiveness } \\
\text { Three-way interaction on integration }\end{array}$ & 8.170 & $1(795)$ & .009 & .004 \\
$\quad \begin{array}{l}\text { Exemplars' sex } \times \text { exemplars' social support } \\
\quad \text { participants' relationship status }\end{array}$ & 3.988 & $1(797)$ & .005 & .046 \\
$\begin{array}{l}\text { Three-way interaction on benevolence } \\
\quad \text { Exemplars' sex } \times \text { exemplars' social support } \\
\quad \text { participants' relationship status }\end{array}$ & 6.424 & $1(796)$ & .007 & .011 \\
\hline
\end{tabular}

Furthermore, the analyses yielded two three-way interactions of (1) exemplars' age $\times$ exemplars' social support $\times$ participants' relationship status on integration (see Figure 1 ) as well as of (2) exemplars' sex $\times$ exemplars' social support $\times$ participants' relationship status on benevolence (see Figure 2), which were already described above. While the Sidak-corrected posthoc comparisons showed no significant mean differences depending on participants' relationship status for the interaction effect on integration, the second interaction effect on benevolence showed that participants who are single are more benevolent towards people with mental illness if they were exposed to male exemplars without social support compared to those who were exposed to female exemplars without social support.

In summary, the participants' relationship status thus has a direct effect on their generalised stigma-related attitudes within the dimension of social restrictiveness and indirectly in combination with other exemplar characteristics across the dimensions of integration and benevolence.

\section{Discussion}

The aim of the current study was to investigate how exemplars with depression affect generalised stigma-related attitudes towards people with mental illness and how different exemplar characteristics (i.e., sex, age, and receipt of social support) and the potential stigmatisers' characteristics (i.e., sex and relationship status) influence the direction of stigma-related attitude changes. Overall, in line with exemplification theory (Zillmann \& Brosius, 2000), our findings confirm that an exemplar with depression has the potential to alter stigma-related attitudes towards people with mental illness. Contrary to our hypotheses, we did not find any direct effects of the exemplars' sex, age, and social support on generalised stigma-related attitudes. As we point out in the limitations' section, a potential explanatory factor could be of a methodological nature. Instead, we found evidence for complex interaction effects of combinations of exemplar characteristics with potential stigmatisers' characteristics on stigma-related attitudes towards people with mental illness in general. In the following, we elaborate on the interactions and effects of (1) the potential stigmatisers' relationship status, and (2) sex. 


\section{Influence of the Stigmatisers' Relationship Status and Social Support}

First, after being exposed to single-case descriptions of young students with depression, people who are single showed more negative generalised stigma-related attitudes towards people with mental illness when the exemplars were depicted as receiving social support compared to exemplars without social support. This effect is partially in line with our assumption that depictions of social support for an exemplar with mental illness have a positive effect on stigma-related attitudes. While the perceived dangerousness of affected individuals is a causal factor for the stigmatisation of people with mental illness (e.g., Corrigan, 2004; Anderson et al., 2015) and social support has an overall positive effect on peoples' wellbeing (e.g., Bryson \& Bogart, 2020; Carriello et al., 2020; DeMartini et al., 2020; Yao et al., 2015), it is reasonable to assume that the depiction of social support for an exemplar with mental illness positively affects the perceived dangerousness of affected individuals and, thus, evokes less stigmatisation. Moreover, the effect of depicting a socially supported exemplar with mental illness can further be related to the recovery approach (see van Weeghel et al., 2019 for an overview). A social-support perspective could be associated with the positive recovery process of a person with mental illness, which has been found to positively affect stigmatisation in prior research (e.g., Corrigan et al., 2013; McGinty et al., 2015; Röhm, 2017). Future studies should investigate whether the effect occurs exclusively after exposure to younger exemplars with depression and only among people who are single.

Second, single-case descriptions of socially supported male students with depression evoked more benevolence than descriptions of socially supported female students in people who are single. This is partially in line with our assumption that male exemplars with depression generally evoke less stigma-related attitudes towards people with mental illness than female exemplars. Furthermore, it supports the notion that depression is generally perceived as more female-typical, thus leading female exemplars to evoke more stigmatisation in the context of depression and mental illness (van Driel et al., 2018; Wirth \& Bodenhaus, 2009). The extent to which this effect is also evident exclusively with the depiction of social support for an exemplar with mental illness and solely among people who are single would need to be clarified in future studies.

Third, single-case descriptions of young students with depression evoked more positive generalised attitudes towards the integration of people with mental illness among people who were not in a relationship when the exemplar was socially supported compared to exemplars who were not socially supported. This rather indirect effect of the exemplars' age could be explained by the average age of our sample. As most of the participants were of a similar age to the younger exemplar with mental illness, the likelihood of identifying with the younger exemplar was increased. Just as Yang et al. (2008) found, higher levels of identification with others could lead to a higher likelihood of willingness to help others. Identification could also explain the indirect effect of the exemplars' age on attitudes towards the integration of people with mental illness in the present study.

According to our research question, the findings of the current study indicate that the potential stigmatisers' relationship status indirectly influences generalised prosocial attitudes (i.e., benevolence, attitudes towards integration) towards people with mental illness after exposure to exemplars with depression, depending upon the exemplars' sex, age, and level of social support. Under two conditions people who are single held more prosocial attitudes towards people with 
mental illness: first, under the condition that they were exposed to male exemplars without social support, and second, under the condition that they were exposed to young exemplars with social support. Research should further investigate this complex interaction patterns between the stigmatisers' sex and relationship status to better understand the stronger prosociality observed after the exposure of male exemplars with depression. Furthermore, in future studies, it should also be qualitatively investigated why the positive influences of the aforementioned exemplar characteristics on attitudes towards the integration of people with mental illness are only evident among people who are single. At this point, we can only speculate that people who are single possibly show greater openness and more empathy towards vulnerable individuals and groups than people who are in a relationship and, thus, stigmatise people with mental illness less. This hypothesis would also be supported by the following finding that generalised negative attitudes towards the social restrictiveness of people with mental illness were directly influenced by stigmatisers' relationship status. Contrary to the results of Hastall et al. (2016) in the context of the exemplification and stigmatisation of people with disabilities, we found that people in a relationship were more stigmatising towards people with mental illness compared to singles. However, due to the very small strength of the main effect found, this result should only be interpreted cautiously and requires replication.

To conclude our research question, the relationship status of people who were exposed to exemplars with depression seems to influence generalised stigma-related attitudes towards people with mental illness, at least indirectly. However, whether the relationship status leads to more or less stigmatising attitudes cannot be definitively answered. Based on the current state of research, it is difficult to clarify the underlying reasons. Further and especially qualitative research is needed to gain a deeper understanding of these psychological and sociological processes.

\section{Influence of the Stigmatisers' Sex and Social Support}

Furthermore, in line with our hypotheses and other prior research (e.g., Anderson et al., 2015; Corrigan et al., 2003; Dolphin and Hennessey, 2016; Mackenzie et al., 2019; Röhm, 2017; Thibodeau et al., 2015), we found that women showed less negative generalised stigma-related and more positive prosocial attitudes towards people with mental illness after being exposed to exemplars with depression than men did. As other scholars have argued, women often demonstrate stronger feelings of empathy (e.g., Christov-Moore et al., 2014; Schieman \& Gundy, 2000; Toussaint \& Webb, 2005) and pity (e.g., Corrigan \& Watson, 2007), which thus could explain the lower stigmatisation tendency of women compared to men. Another possible explanation for the sex differences in the context of mental illness stigma could be the higher prevalence of depression among women (e.g., Kessler et al., 2012; Piccinelli and Wilkinson, 2000; Salk et al., 2017). The higher prevalence is also associated with greater knowledge of women about mental illness (Burns \& Rapee, 2006), and thus would lead to a lower tendency of stigmatisation among women (e.g., Morgan et al., 2018). Furthermore, more positive and less stigmatising attitudes of women towards mental illness could be attributed to more contact with affected women as can be seen in Allport's (1954) contact hypothesis (e.g., Morgan et al., 2018). 


\section{Implications}

Our findings show that exemplars of people with mental illness have the potential to influence the public's stigmatisation of people with mental illness. Their stigmatising or destigmatising potential firstly depends on characteristics of the exemplars themselves, secondly on characteristics of the stigmatisers and thirdly on the situational context (here: studies) in which exemplars are presented. For health communication experts, this finding implies that the negative consequences such as an (unintentional) reinforcement of stigmatising attitudes towards vulnerable individuals and groups such as people with mental illness need to be considered when designing health messages. From our perspective, it is relevant that public health experts are very familiar with the characteristics of their potential audiences in order to communicate in a targeted and stigma-sensitive manner. Even though our findings on the influence of the potential stigmatisers' relationship status as well as the depiction of social support for a person with depression on stigmatising attitudes towards people with mental illness are not yet clear and need further investigation, they show the potential of considering social factors in the context of health communication.

\section{Limitations}

Apart from the practical implications of the findings, the present study has a number of limitations that need to be considered when interpreting the results and conducting further research. First, the study participants were intentionally limited to students. This narrow sample selection limits the possibilities for generalisation of the results as the sample mostly consisted of younger participants with a higher educational background, despite the age ranging from 16-70. The relatively small sample size of $N=854$ should also be considered in regard to the generalisability of the results.

Second, the comparatively small effect sizes should be considered. Even though the manipulation check was successful, some manipulations did not yield the desired effects, which could mean that they were not as well-operationalised or influential as previously thought. In further research, a stimulus check should be included within the survey to ensure the manipulations performed as intended. It should also be noted that the variable social support is tied to the recovery of the depicted person since receiving social support facilitated a positive outcome while the absence of the aforesaid support ended in a negative outcome. The results regarding the effects of social support should therefore be viewed as confounded by the recovery perspective. Future research would have to examine both aspects separately.

Turning to the participants, we examined the effect of the participants' relationship status on stigmatising attitudes. However, while we did find some effects of the participants' relationship status, it should be noted that no information concerning either the type or the quality of the relationship was gathered. These additional variables might give a more comprehensive view of how relationship status affects stigmatising attitudes and whether all types of relationship follow the same or different patterns. For this reason, aspects such as the type and quality of the participants' relationships should be included in future research.

Finally, it should be noted that in our stimuli, we describe a student with depressive symptoms, even if we did not label him/her as 'depressive'. The extent to which the emerged effects would apply when describing people with other mental health problems (e.g., schizophrenia) would need to be investigated in further research. 


\section{Conclusion}

In conclusion, although contrary to our hypotheses we did not find the main effects of the key characteristics of the exemplars with depression, we were able to show that the exemplars' characteristics (i.e., sex, age, and social support) and the potential stigmatisers' characteristics (i.e., sex and relationship status) influenced stigmatising attitudes towards people with mental illness; however, further research is needed to replicate and explain the complex effect patterns. Moreover, the effects of stigmatisers' relationship status and depictions of social support for an exemplar with mental illness might be new aspects to consider in the context of strategic health and anti-stigma communication. Future research in the field of exemplification and stigmatisation should also consider the interaction of different characteristics of potential stigmatisers and exemplars with mental illness in more detail. The effects of depicting (structural) social support in exemplars with mental illness are rather complex and need further investigation. We propose re-examining the social factors in a mixed-method design while considering qualitative and quantitative research methods. Overall, the current study provides interesting and promising starting points for future research.

\section{Notes}

1. Sidak-correction was used because it is recommended when comparing different independent variables. Compared to the Bonferroni-correction Sidak-correction has a tiny bit more power (e.g., Glantz, 2005).

\section{Funding}

There has not been any particular funding for this project.

\section{Conflict of Interest}

We have no potential conflict of interest to declare.

\section{References}

Abdullah, T., \& Brown, T. L. (2020). Diagnostic labelling and mental illness stigma among black Americans: An experimental vignette study. Stigma and Health, 5(1), 11-21. https://doi.org/10.1037/sah0000162

Ajzen, I. (1985). From intentions to actions: A theory of planned behavior. In J. Kuhl \& J. Beckmann (Eds.), Action control. From cognition to behavior (pp. 11-39). Springer.

Allport, G. W. (1954). The nature of prejudice. Addison-Wesley.

American Psychiatric Association (2013). Diagnostic and statistical manual of mental disorders. $D S M-V\left(5^{\text {th }}\right.$ ed. $)$. 
Anderson, K. N., Jeon, A. B., Blenner, J. A., Wiener, R. L., \& Hope, D. A. (2015). How people evaluate others with social anxiety disorder: A comparison to depression and general mental illness stigma. American Journal of Orthopsychiatry, 85(2), 131-138. https://doi.org/10.1037/ort0000046

Angermeyer, M. C., Heiss, S., Kirschenhofer, S., Ladinser, E., Löffler, W., Schulze, B., \& Swiridoff, M. (2003). Die deutsche Version des Community-Attitudes-toward-the-MentallyIll (CAMI)-Inventars [The German version of the Community-Attitudes-toward-the-MentallyIll (CAMI)-Inventory]. Psychiatrische Praxis, 30(4), 202-206. https://doi.org/10.1055/s-200339493

Baer, N., Sikorski, C., Luppa, M., Riedel-Heller, S., \& Schomerus, G. (2015). Das Stigma Depression - Eine Interaktion zwischen öffentlichem Diskurs und Erfahrungsberichten Betroffener [The depression stigma - An interaction between public discourse and reports of persons concerned]. Psychiatrische Praxis, 43(3), Article: e1-e8. https://doi.org/10.1055/s0034-1387440

Bahlmann, J., Schomerus, G., \& Angermeyer, M. C. (2015). Nicht ganz dasselbe: Krankheitsvorstellungen von Burnout und Depression in der Allgemeinbevölkerung [Not quite the same: Illness beliefs regarding burnout and depression among the general population]. Psychiatrische Praxis, 42(8), 443-447. https://doi.org/10.1055/s-0034-1387365

Bambina, A. (2007). Online social support: The interplay of social networks and computermediated communication. Cambria Press.

Barney, L. J., Griffiths, K. M., Jorm A. F., \& Christensen, H. (2006). Stigma about depression and its impact on help-seeking intentions. Australian and New Zealand Journal of Psychiatry, 40(1), 51-54. https://doi.org/10.1111/j.1440-1614.2006.01741.x

Batterham, P. J., Griffiths, K. M., Barney, L. J., \& Parsons, A. (2013). Predictors of generalized anxiety disorder stigma. Psychiatry Research, 206(2), 282-286.

https://doi.org/10.1016/j.psychres.2012.11.018

Bryant, C., Bei, B., Gilson, K., Komiti, A., Jackson, H., \& Judd, F. (2012). The relationship between attitudes to aging and physical and mental health in older adults. International Psychogeriatrics, 24(10), 1674-1683. https://doi.org/10.1017/s1041610212000774

Bryson, B. A., \& Bogart, K. R. (2020). Social support, stress, and life satisfaction among adults with rare diseases. Health Psychology, 39(10), 912-920. https://doi.org/10.1037/hea0000905

Burns, J. R., \& Rapee, R. M. (2006). Adolescent mental health literacy: Young people's knowledge of depression and help seeking. Journal of Adolescence, 29(2), 225-239. https://doi.org/10.1016/j.adolescence.2005.05.004

Cariello, A. N., Tyler, C. M., Perrin, P. B., Jackson, B., Librandi, H., Sutter, M., Maher, K. E., Goldberg, L. D., \& Feldman, M. J. (2020). Influence of social support on the relation between stigma and mental health in individuals with burn injuries. Stigma and Health, 6(2), 209-215. https://doi.org/10.1037/sah0000250

Christov-Moore, L., Simpson, E. A., Coudé, G., Grigaityte, K., Iacoboni, M., \& Ferrari, P. F. (2014). Empathy: Gender effects in brain and behavior. Neuroscience \& Biobehavioral Reviews, 46(4), 604-627. https://doi.org/10.1016/j.neubiorev.2014.09.001

Chung, A. H., \& Slater, M. D. (2013). Reducing stigma and out-group distinctions through perspective-taking in narratives. Journal of Communication, 63(5), 894-911. https://doi.org/10.1111/jcom.12050 
Clement, S., Lassman, F., Barley, E., Evans-Lacko, S., Williams, P., Yamaguchi, S., \& Thornicroft, G. (2013). Mass media interventions for reducing mental health-related stigma. Cochrane Database of Systematic Reviews, 7(7), Article: CD009453. https://doi.org/10.1002/14651858.cd009453.pub2

Corrigan, P. (2004). How stigma interferes with mental health care. American Psychologist, 59(7), 614-625. https://doi.org/10.1037/0003-066X.59.7.614

Corrigan, P. W., Markowski, F. E., Watson, A., Rowan, D., \& Kubiak, M. A. (2003). An attribution model of public discrimination towards persons with mental illness. Journal of Health and Social Behavior, 44(2), 162-179.

Corrigan, P. W., Powell, K. J., \& Michaels, P. J. (2013). The effects of news stories on the stigma of mental illness. The Journal of Nervous and Mental Diseases, 201(3), 179-182. https://doi.org/10.1097/nmd.0b013e3182848c24

Corrigan, P. W., \& Watson, A. C. (2007). The Stigma of Psychiatric Disorders and the Gender, Ethnicity, and Education of the Perceiver. Community Mental Health Journal, 43, 439-458. https://doi.org/10.1007/s10597-007-9084-9

Crisp, A., Gelder, M., Goddard, E., \& Meltzer, H. (2005). Stigmatization of people with mental illnesses: a follow-up study within the Changing Minds campaign of the Royal College of Psychiatrists. World psychiatry, 4(2), 106-113.

Dear, M. J., \& Taylor, M. S. (1979). Scaling community attitudes towards the mentally ill. Schizophrenia Bulletin, 7(2), 225-240. https://doi.org/10.1093/schbul/7.2.225

DeMartini, L., Mizock, L., Drob, S., Nelson, A., \& Fisher, W. (2020). The barriers and facilitators to serious mental illness: Recovery postincarceration. Psychological Services. Advance online publication. https://doi.org/10.1037/ser0000431

Deutsche Gesellschaft für Psychiatrie und Psychotherapie, Psychosomatik und Nervenheilkunde e. V. (2020, August 30). Zahlen und Fakten der Psychiatrie und Psychotherapie. Stand 2019 [Facts and figures of psychiatry and psychotherapy. Status: July, 2019]. https://www.dgppn.de/_Resources/Persistent/154e18a8cebe41667ae22665162be21ad726e8b8 /Factsheet_Psychiatrie.pdf

Dolphin, L., \& Hennessy, E. (2016). Depression stigma among adolescents in Ireland. Stigma and Health, 1(3), 185-200. https://doi.org/10.1037/sah0000025

Festinger (1954). A theory of social comparison process. Human Relations, 7(2), 117-140. https://doi.org/10.1177/001872675400700202

Frankham, E. (2019). A modified framework for identifying stigma: News coverage of persons with mental illness killed by police. Stigma and Health, 4(1), 62-71. https://doi.org/10.1037/sah0000121

GBD 2015 Disease and Injury Incidence and Prevalence Collaborators. (2016). Global, regional, and national incidence, prevalence, and years lived with disability for 354 diseases and injuries for 195 countries and territories, 1990-2017: A systematic analysis for the Global Burden of Disease Study 2017. The Lancet, 392, 1789-1858. https://doi.org/10.1016/S01406736(18)32279-7

Glantz, S. A. (2005). Primer of biostatistics ( $6^{\text {th }}$ ed.). McGraw-Hill Medical Pub.

Griffiths, K. M., Christensen, H., \& Jorm, A. F. (2008). Predictors of depression stigma. BMC Psychiatry, 8, Article: 25. https://doi.org/10.1186/1471-244X-8-25 
Gwarjanski, A. R., \& Parrott, S. (2018). Schizophrenia in the news: The role of news frames in shaping online reader dialogue about mental illness. Health Communication, 33(8), 954-961. https://doi.org/10.1080/10410236.2017.1323320

Hahm, S., Muehlan, H., Stolzenburg, S., Tomczyk, S., Schmidt, S., \& Schomerus, G. (2020). How stigma interferes with symptom awareness: Discrepancy between objective and subjective cognitive performance in currently untreated persons with mental health problems. Stigma and Health, 5(2), 146-157. https://doi.org/10.1037/sah0000184

Hastall, M. R., Ritterfeld, U., Finzi, J. A., \& Röhm, A. (2016). Stigmatisierungen und Destigmatisierungen von Personen mit gesundheitlichen Einschränkungen oder Behinderungen: Ein weiterer Fallbeispieleffekt? [Stigmatisation and destigmatisation of people with health restrictions or disabilities: Another effect of exemplification?] In A. L. Camerini, R. Ludolph, \& F. Rothenfluh (Eds.), Gesundheitskommunikation im Spannungsfeld zwischen Theorie und Praxis [Health communication in the area of conflict between theory and practice] (pp. 169-182). Nomos.

Hebl, M. R., \& Kleck, R. E. (2000). The social consequences of physical disability. In T. F. Heatherton, R. E. Kleck, M. R. Hebl, \& J. G. Hull (Eds.), The social psychology of stigma (pp. 419-439). Guilford Press.

Henderson, C., Evans-Lacko, S., \& Thornicroft, G. (2013). Mental illness stigma, help seeking, and public health programs. American Journal of Public Health, 103(5), 777-780.

https://doi.org/10.2105/AJPH.2012.301056

Kessler, R. C., Petukhova, M., Sampson, N. A., Zaslavsky, A. M., \& Wittchen, H.-U. (2012). Twelve-month and lifetime prevalence and lifetime morbid risk of anxiety and mood disorders in the United States. International Journal of Methods in Psychiatric Research, 21(3), 169-184. https://doi.org/10.1002/mpr.1359

Krämer, B. (2015). Fallbeispieleffekte [Exemplification effects]. Nomos.

Krämer, B., \& Peter, C. (2020). Exemplification effects: A meta-analysis. Human Communication Research, 46(2), 192-221. https://doi.org/10.1093/hcr/hqz024

Lasalvia, A., Zoppei, S., Van Bortel, T., Bonetto, C., Cristofalo, D., Wahlbeck, K., VasseurBacle, S., Van Audenhove, C., van Weeghel, J., Reneses, B., Germanavicius, A., Economou, M., Lanfredi, M., Ando, S., Sartorius, N., Lopez-Ibor, J., Thornicroft, G., \& ASPEN/INDIGO Study Group (2015). Global pattern of experienced and anticipated discrimination reported by people with major depressive disorder: A cross-sectional survey. The Lancet, 381, 55-62. https://doi.org/10.1016/s0140-6736(12)61379-8

Lucier-Greer, M., \& Adler-Baeder, F. (2011). An examination of gender role attitude change patterns among continuously married, divorced, and remarried individuals. Journal of Divorce \& Remarriage, 52(4), 225-243. https://doi.org/10.1080/10502556.2011.556977

Mackenzie, C. S., Visperas, A., Ogrodniczuk, J. S., Oliffe, J. L., \& Nurmi, M. A. (2019). Age and sex differences in self-stigma and public stigma concerning depression and suicide in men. Stigma and Health, 4(2), 233-241. https://doi.org/10.1037/sah0000138

McGinty, E. E., Webster, D. W., Jarlenski, M., \& Barry, C. L. (2014). News media framing of serious mental illness and gun violence in the United States, 1997-2012. American Journal of Public Health, 104(3), 406-413. https://doi.org/10.2105/ajph.2013.301557 
McGinty, E. E., Goldman, H. H., Pescosolido, B., \& Barry, C. L. (2015). Portraying mental illness and drug addictions as treatable health conditions: Effects of randomized experiment on stigma and discrimination. Social Science \& Medicine, 126, 73-85. https://doi.org/10.1016/j.socscimed.2014.12.010

Morgan, S. E., Movius, L., \& Cody, M. J. (2009). The power of narratives: The effect of entertainment television organ donation storylines on the attitudes, knowledge, and behaviors of donors and nondonors. Journal of Communication, 59(1), 135-151.

https://doi.org/10.1111/j.1460-2466.2008.01408.x

Morgan, A. J., Reavley, N. J., Ross, A., Too, L. S., Jorm, A. F. (2018). Interventions to reduce stigma towards people with severe mental illness: Systematic review and meta-analysis. Journal of psychiatric research, 103, 120-133. https://doi.org/10.1016/j.jpsychires.2018.05.017

Mouzas, O. D., Angelopoulos, N. V., \& Liakos, A. (2008). Public opinions about mental illness in a Greek area: The influence of socio-demographic factors. Psychiatriki, 19(4), 337-349.

Mueller, B., Nordt, C., Lauber, C., Rueesch, P., Meyer, P. C., \& Roessler, W. (2006). Social support modifies perceived stigmatization in the first years of mental illness: A longitudinal approach. Social Science \& Medicine, 62(1), 39-49. https://doi.org/10.1016/j.socscimed.2005.05.014

Park, S., \& Park, K. S. (2014). Family stigma: A concept analysis. Asian Nursing Research, 8(3), 165-171. https://doi.org/10.1016/j.anr.2014.02.006

Perry, B. L. (2011). The labeling paradox: Stigma, the sick role, and social networks in mental illness. Journal of Health and Social Behavior, 52, 460-477. https://doi.org/10.1177/0022146511408913

Peter, C., Rossmann, C., \& Keyling, T. (2014). Exemplification 2.0: Roles of direct and indirect social information in conveying health messages through social network sites. Journal of Media Psychology, 26(1), 19-28. https://doi.org/10.1027/1864-1105/a000103

Pettijohn II, T. F., Naples, G. M., \& McDermott, L. A. (2010). Gender, college year, and romantic relationship status differences in embarrassment and self attitudes of college students. Individual Differences Research, 8(3), 164-170.

Piccinelli, M., \& Wilkinson, G. (2000). Gender differences in depression. British Journal of Psychiatry, 177(6), 486-492. https://doi.org/10.1192/bjp.177.6.486

Reimer, B., Lyons, T., Ferguson, N., \& Polanco, G. (2008). Social capital as social relations: The contribution of normative structures. The Sociological Review, 56(2), 256-274. https://doi.org/10.1111/j.1467-954X.2008.00787.x

Riles, J. M. (2020). The social effect of exposure to mental illness media portrayals: Influencing interpersonal interaction intentions. Psychology of Popular Media Culture, 9(2), 145-154. https://doi.org/10.1037/ppm0000217

Röhm, A. (2017). Stigmatisierung und Entstigmatisierung von Menschen mit Behinderungen: Einfluss unterschiedlicher medialer Darstellungen auf Einstellungen und Handlungsintentionen [Stigmatization and destigmatization of people with disability: the influence of different media presentations on attitudes and behavioral intentions; Doctoral dissertation, TU Dortmund]. https://doi.org/10.17877/DE290R-18180

Salk, R. H., Hyde, J. S., \& Abramson, L. Y. (2017). Gender differences in depression in representative national samples: Meta-analyses of diagnoses and symptoms. Psychological Bulletin, 143(8), 783-822. https://doi.org/10.1037/bul0000102 
Schieman, S., \& Gundy, K. V. (2000). The personal and social links between age and selfreported empathy. Social Psychology Quarterly, 63(2), 152-174.

https://doi.org/10.2307/2695889

Shanahan, J., \& Morgan, M. (1999). Television and its viewers: Cultivation theory and research. Cambridge University Press.

Spence, P. R., Lachlan, K. A., Westerman, D., Lin, X., Harris, C. J., Sellnow, T. L., \& SellnowRichmond, D. D. (2015). Exemplification effects: Responses to perceptions of risk. Journal of Risk Research, 20(5), 590-610. https://doi.org/10.1080/13669877.2015.1100658

Tajfel, H., \& Turner, J. C. (1986). The social identity theory of intergroup behavior. In S. Worchel \& W. G. Austin (Eds.), Psychology of intergroup relation (pp. 7-24). Hall Publishers.

Taylor, S. E. (2011). Social support: A review. In H. S. Friedman (Ed.), The handbook of health psychology (pp. 189 -214). Oxford University Press.

Thibodeau, P. H., Fein, M. J., Goodbody, E. S., \& Flusberg, S. J. (2015). The depression schema: How labels, features, and causal explanations affect lay conceptions of depression. Frontiers in Psychology, 6, Article: 1728. https://doi.org/10.3389/fpsyg.2015.01728

Toussaint, L., \& Webb, J. R. (2005). Gender differences in the relationship between empathy and forgiveness. The Journal of Social Psychology, 145(6), 673-685. https://doi.org/10.3200/socp.145.6.673-686

Van Driel, I. I., Myrick, J. G., Pavelko, R. L., Grabe, M. E., Vettehen, P. H., Kleemans, M., \& Schaap, G. (2018). The role of media use in the genderization of disease: The interplay of sex, culture, and cultivation. The International Journal of Communication and Health, 13, 1-10.

Van Weeghel, J., van Zelst, C., Boertien, D., \& Hasson-Ohayon, I. (2019). Conceptualizations, assessments, and implications of personal recovery in mental illness: A scoping review of systematic reviews and meta-analyses. Psychiatric Rehabilitation Journal, 42(2), 169-181. https://doi.org/10.1037/prj0000356

Vyncke, B., \& van Gorp, B. (2018). An experimental examination of the effectiveness of framing strategies to reduce mental health stigma. Journal of Health Communication, 23(10), 899-908. https://doi.org/10.1080/10810730.2018.1538272

Wahl, O. F. (1996). Schizophrenia in the news. Psychiatric Rehabilitation Journal, 20(1), 51-54. https://doi.org/10.1037/h0095401

Wang, W. (2020) Exemplification and stigmatization of the depressed: Depression as the main topic versus an incidental topic in national US news coverage. Health Communication, 35(8), 1033-1041. https://doi.org/10.1080/10410236.2019.1606874

World Health Organization (2004). ICD-10: International statistical classification of diseases and related health problems $\left(10^{\text {th }}\right.$ revision, 2 nd ed.). WHO.

World Health Organization (2020, August 30). Depression. [Status: May, 2017]. WHO. https://www.who.int/news-room/fact-sheets/detail/depression

Wirth, J., \& Bodenhausen, G. V. (2009). The role of gender in mental-illness stigma. A national experiment. Psychological Science, 20(2), 169-173. https://doi.org/10.1111/j.14679280.2009.02282.x 
Wright, A., Jorm, A. F, \& Mackinnon, A. J. (2012). Labels used by young people to describe mental disorders: Which ones predict effective help-seeking choices? Social Psychiatry and Psychiatric Epidemiology, 47, 917-926. https://doi.org/10.1007/s00127-011-0399-z

Yang, L. H., Link, B. G., \& Phelan, J. C. (2008). Stigma measurement approaches: Conceptual origins and current applications. In J. Arboleda-Flórez \& N. Sartorius (Eds.), Understanding the stigma of mental illness: Theory and interventions (pp. 175-192). John Wiley \& Sons.

Yao, T., Zheng, Q., \& Fan, X. (2015). The impact of online social support on patients' quality of life and the moderating role of social exclusion. Journal of Service Research, 18(3), 369-383. https://doi.org/10.1177/1094670515583271

Yap, M. B. H., Reavley, N., Mackinnon, A. J., \& Jorm, A. F. (2013). Psychiatric labels and other influences on young people's stigmatizing attitudes: Findings from an Australian national survey. Journal of Affective Disorders, 148(2), 299-309. https://doi.org/10.1016/j.jad.2012.12.015

Zillmann, D. (2008). Exemplification theory of media influence. In J. Bryant \& D. Zillmann (Eds.), Media effects: Advances in theory and research (pp. 19-42). Lawrence Erlbaum Associates.

Zillmann, D., \& Brosius, H.-B. (2000). Exemplification in communication: The influence of case reports on the perception of issues. Lawrence Erlbaum Associates.

\section{Author Contributions}

Conceptualisation (main idea, theory): Michélle Möhring, Natascha Krick, \& Anika Ditze Project administration: Michélle Möhring

Methodology (design, operationalization): Natascha Krick, Anika Ditze, \& Michélle Möhring

Data collection: Natascha Krick, Anika Ditze, \& Michélle Möhring

Data analysis: Michélle Möhring \& Anika Ditze

Writing - original draft: Michélle Möhring

Writing - review \& editing: Michélle Möhring, Natascha Krick, \& Anika Ditze

\section{Author Biographies}

Michélle Möhring is currently a doctoral researcher at the Faculty of Rehabilitation Sciences at TU Dortmund University. Her research interests include anti-stigma and health communication as well as the role of moral intuitions for the stigmatisation of marginalised individuals and groups.

Natascha Krick is currently a Master's student at the Faculty of Rehabilitation Sciences at TU Dortmund University. Her research interests include anti-stigma and health communication in the context of mental illness.

Anika Ditze completed her Master's degree in Rehabilitation Sciences at the Faculty of Rehabilitation Sciences at TU Dortmund University. Her research interests include anti-stigma and health communication in the context of mental illness. 


\section{Appendix}

\section{Different Stimulus Versions}

\section{Stimulus 1}

Description: Exemplar depicting a young female student with social support.

Manipulations:

Exemplar's Age: Young

Exemplar's Sex: Female

Story Ending: Social Support

Original Stimulus Die 24-jährige Laura fühlt seit einiger Zeit eine innere Leere. Im Studium fehlt ihr (German): die Kraft und Motivation, sich so anzustrengen, wie sie es vor einem Jahr konnte. Selbst wenn sie die Kraft dazu hätte, bereiten ihr Konzentrationsstörungen Schwierigkeiten. Hinzu kommen die Versagensängste, dass sie in ihren jungen Jahren dem Studium nicht gewachsen ist und dieses nicht erfolgreich bewältigen kann. Auch zu Hause ist ihre Stimmung oft gedrückt, sodass sie eigentlich keine Lust hat, sich mit ihren Freunden zu treffen. Zusätzlich leidet sie unter Schlafstörungen, was dazu führt, dass sie oft sehr müde ist und den Alltag kaum aus eigener Kraft bewältigen kann.

Lauras Freunden ist Lauras gedrückte Stimmung bereits aufgefallen. Sie versuchen wiederholt, Laura zu gemeinsamen Aktivitäten zu motivieren und sie aufzumuntern. Auch wenn es schwierig ist, lassen ihre Freunde den Kontakt nicht abbrechen. Ihre Familie kommt sie regelmäßig besuchen und auch diese versucht, zusammen mit Laura etwas zu unternehmen, was ihr Spaß machen könnte. Zusätzlich telefoniert ihre Familie täglich mit ihr, um zu sehen, wie es ihr geht. Aufgrund des sozialen Rückhalts fühlt sich Laura zeitweise besser und sie kann ihr Studium in ihren jungen Jahren weiter fortsetzen.

English 24-year-old Laura has been feeling hollow for some time. She lacks the energy and Translation: motivation to try as hard as she used to be able to a year ago. Even if she could muster the energy, difficulties with concentration hinder her. On top of that is her fear of failure that she is not capable of doing her course even at her young age and that she cannot successfully get through it. Even at home, her mood is low, resulting in her not wanting to meet up with her friends. In addition, she has trouble sleeping, causing her to be tired a lot and frequently preventing her from managing everyday life on her own.

Laura's friends have already become aware of her low mood. They have tried multiple times to motivate Laura to participate in activities with them and to cheer her up. Even though it is hard, her friends have not let contact break off between them. Her family visits her regularly and they also try to do some activities together that might be fun for her. In addition, her family calls every day to see how she is doing. As a result of this social support, Laura feels better from time to time and can resume her studies. 


\section{Stimulus 2}

Description: $\quad$ Exemplar depicting a young female student without social support.

Manipulations: Exemplar's Age: Young

Exemplar's Sex: Female

Story Ending: No Social Support

Original Stimulus Die 24-jährige Laura fühlt seit einiger Zeit eine innere Leere. Im Studium fehlt ihr (German): die Kraft und Motivation, sich so anzustrengen, wie sie es vor einem Jahr konnte. Selbst wenn sie die Kraft dazu hätte, bereiten ihr Konzentrationsstörungen Schwierigkeiten. Hinzu kommen die Versagensängste, dass sie in ihren jungen Jahren dem Studium nicht gewachsen ist und dieses nicht erfolgreich bewältigen kann. Auch zu Hause ist ihre Stimmung oft gedrückt, sodass sie eigentlich keine Lust hat, sich mit ihren Freunden zu treffen. Zusätzlich leidet sie unter Schlafstörungen, was dazu führt, dass sie oft sehr müde ist und den Alltag kaum aus eigener Kraft bewältigen kann.

Lauras Freunden ist Lauras gedrückte Stimmung bereits aufgefallen, aber sie versuchen trotzdem wiederholt, sie zu einem Treffen zu überreden. Nachdem Laura immer wieder ablehnt, fragen Lauras Freunde seltener nach ihr. Die Versuche, sie weiterhin in Aktivitäten einzubinden, bleiben schließlich aus. $\mathrm{Zu}$ ihrer Familie verringert sich nach und nach der Kontakt. Dadurch, dass Laura sich nicht mehr bei ihnen meldet, bricht auch hier der Kontakt nach einiger Zeit vollständig ab. Laura fühlt sich nach wie vor schlecht und denkt darüber nach, ihr Studium in ihren jungen Jahren abzubrechen.

English 24-year-old Laura has been feeling hollow for some time. She lacks the energy and Translation: motivation to try as hard as she used to be able to a year ago. Even if she could muster the energy, difficulties with concentration hinder her. On top of that is her fear of failure that she is not capable of doing her course even at her young age and that she cannot successfully get through it. Even at home, her mood is low, resulting in her not wanting to meet up with her friends. In addition, she has trouble sleeping, causing her to be tired a lot and frequently preventing her from managing everyday life on her own.

Laura's friends have already become aware of her low mood. They have tried multiple times to motivate Laura to participate in activities with them and to cheer her up. After Laura repeatedly rejects, Laura's friends ask for her less often. Attempts to keep her involved in activities eventually fail. Contact with her family gradually decreases. Because Laura no longer contacts them, contact breaks off completely after some time. Laura still feels bad and thinks about breaking off studies at her young age. 


\section{Stimulus 3}

Description: $\quad$ Exemplar depicting an older female student with social support.

Manipulations: $\quad$ Exemplar's Age: Old

Exemplar's Sex: Female

Story Ending: Social Support

Original Stimulus Die 56-jährige Gertrud fühlt seit einiger Zeit eine innere Leere. Im Studium fehlt ihr (German): die Kraft und Motivation, sich so anzustrengen, wie sie es vor einem Jahr konnte. Selbst wenn sie die Kraft dazu hätte, bereiten ihr Konzentrationsstörungen Schwierigkeiten. Hinzu kommen die Versagensängste, dass sie in ihrem hohen Alter dem Studium nicht gewachsen ist und dieses nicht erfolgreich bewältigen kann. Auch zu Hause ist ihre Stimmung oft gedrückt, sodass sie eigentlich keine Lust hat, sich mit ihren Freunden zu treffen. Zusätzlich leidet sie unter Schlafstörungen, was dazu führt, dass sie oft sehr müde ist und den Alltag kaum aus eigener Kraft bewältigen kann.

Gertrud Freunden ist Gertruds gedrückte Stimmung bereits aufgefallen. Sie versuchen wiederholt, Gertrud zu gemeinsamen Aktivitäten zu motivieren und sie aufzumuntern. Auch wenn es schwierig ist, lassen ihre Freunde den Kontakt nicht abbrechen. Ihre Familie kommt sie regelmäßig besuchen und auch diese versucht, zusammen mit Gertrud etwas zu unternehmen, was ihr Spaß machen könnte. Zusätzlich telefoniert ihre Familie täglich mit ihr, um zu sehen, wie es ihr geht. Aufgrund des sozialen Rückhalts fühlt sich Gertrud zeitweise besser und sie kann ihr Studium in ihrem hohen Alter weiter fortsetzen.

English 56-year-old Gertrude has been feeling hollow for some time. She lacks the energy Translation: and motivation to try as hard as she used to be able to a year ago. Even if she could muster the energy, difficulties with concentration hinder her. On top of that is her fear of failure that she is not capable of doing her course at her older age and that she cannot successfully get through it. Even at home, her mood is low, resulting in her not wanting to meet up with her friends. In addition, she has trouble sleeping, causing her to be tired a lot and frequently preventing her from managing everyday life on her own.

Gertrude's friends have already become aware of her low mood. They have tried multiple times to motivate Gertrude to participate in activities with them and to cheer her up. Even though it is hard, her friends have not let contact break off between them. Her family visits her regularly and they also try to do some activities together that might be fun for her. In addition, her family calls every day to see how she is doing. As a result of this social support, Gertrude feels better from time to time and can resume her studies. 


\section{Stimulus 4}

Description: $\quad$ Exemplar depicting an older female student without social support.

Manipulations: Exemplar's Age: Old

Exemplar's Sex: Female

Story Ending: No Social Support

Original Stimulus Die 56-jährige Gertrud fühlt seit einiger Zeit eine innere Leere. Im Studium fehlt ihr (German): die Kraft und Motivation, sich so anzustrengen, wie sie es vor einem Jahr konnte. Selbst wenn sie die Kraft dazu hätte, bereiten ihr Konzentrationsstörungen Schwierigkeiten. Hinzu kommen die Versagensängste, dass sie in ihrem hohen Alter dem Studium nicht gewachsen ist und dieses nicht erfolgreich bewältigen kann. Auch zu Hause ist ihre Stimmung oft gedrückt, sodass sie eigentlich keine Lust hat, sich mit ihren Freunden zu treffen. Zusätzlich leidet sie unter Schlafstörungen, was dazu führt, dass sie oft sehr müde ist und den Alltag kaum aus eigener Kraft bewältigen kann.

Gertruds Freunden ist Gertruds gedrückte Stimmung bereits aufgefallen, aber sie versuchen trotzdem wiederholt sie zu einem Treffen zu überreden. Nachdem Gertrud immer wieder ablehnt, fragen Gertruds Freunde seltener nach ihr. Die Versuche, sie weiterhin in Aktivitäten einzubinden, bleiben schließlich aus. $\mathrm{Zu}$ ihrer Familie verringert sich nach und nach der Kontakt. Dadurch, dass Gertrud sich nicht mehr bei ihnen meldet, bricht auch hier der Kontakt nach einiger Zeit vollständig ab. Gertrud fühlt sich nach wie vor schlecht und denkt darüber nach, ihr Studium in ihrem hohen Alter abzubrechen.

English

Translation:

56-year-old Gertrude has been feeling hollow for some time. She lacks the energy and motivation to try as hard as she used to be able to a year ago. Even if she could muster the energy, difficulties with concentration hinder her. On top of that is her fear of failure that she is not capable of doing her course at her older age and that she cannot successfully get through it. Even at home, her mood is low, resulting in her not wanting to meet up with her friends. In addition, she has trouble sleeping, causing her to be tired a lot and frequently preventing her from managing everyday life on her own.

Gertrude's friends have already become aware of her low mood. They have tried multiple times to motivate Gertrude to participate in activities with them and to cheer her up. Even though it is hard, her friends have not let contact break off between them. Her family visits her regularly and they also try to do some activities together that might be fun for her. In addition, her family calls every day to see how she is doing. As a result of this social support, Gertrude feels better from time to time and can resume her studies. 


\section{Stimulus 5}

Description: $\quad$ Exemplar depicting a young male student with social support.

Manipulations: Exemplar's Age: Young

Exemplar's Sex: Male

Story Ending: Social Support

Original Stimulus Der 24-jährige Phillip fühlt seit einiger Zeit eine innere Leere. Im Studium fehlt ihm (German): die Kraft und Motivation, sich so anzustrengen, wie er es vor einem Jahr konnte. Selbst wenn er die Kraft dazu hätte, bereiten ihm Konzentrationsstörungen Schwierigkeiten. Hinzu kommen die Versagensängste, dass er in seinen jungen Jahren dem Studium nicht gewachsen ist und dieses nicht erfolgreich bewältigen kann. Auch zu Hause ist seine Stimmung oft gedrückt, sodass er eigentlich keine Lust hat, sich mit seinen Freunden zu treffen. Zusätzlich leidet er unter Schlafstörungen, was dazu führt, dass er oft sehr müde ist und den Alltag kaum aus eigener Kraft bewältigen kann.

Phillips Freunden ist Phillips gedrückte Stimmung bereits aufgefallen. Sie versuchen wiederholt, Phillip zu gemeinsamen Aktivitäten zu motivieren und ihn aufzumuntern. Auch wenn es schwierig ist, lassen seine Freunde den Kontakt nicht abbrechen. Seine Familie kommt ihn regelmäßig besuchen und auch diese versucht, zusammen mit Phillip etwas zu unternehmen, was ihm Spaß machen könnte. Zusätzlich telefoniert seine Familie täglich mit ihm, um zu sehen, wie es ihm geht. Aufgrund des sozialen Rückhalts fühlt sich Phillip zeitweise besser und er kann sein Studium in seinen jungen Jahren weiter fortsetzen.

English 24-year-old Phillip has been feeling hollow for some time. He lacks the energy and Translation: motivation to try as hard as he used to be able to a year ago. Even if he could muster the energy, difficulties with concentration hinder him. On top of that is his fear of failure that he is not capable of doing his course even at his young age and that he cannot successfully get through it. Even at home, his mood is low, resulting in him not wanting to meet up with his friends. In addition, he has trouble sleeping, causing him to be tired a lot and frequently preventing him from managing everyday life on his own.

Phillip's friends have already become aware of his low mood. They have tried multiple times to motivate Phillip to participate in activities with them and to cheer him up. Even though it is hard, his friends have not let contact break off between them. His family visits him regularly and they also try to do some activities together that might be fun for him. In addition, his family calls every day to see how he is doing. As a result of this social support, Phillip feels better from time to time and can resume his studies. 


\section{Stimulus 6}

Description: $\quad$ Exemplar depicting a young male student without social support.

Manipulations: Exemplar's Age: Young

Exemplar's Sex: Male

Story Ending: No Social Support

Original Stimulus Der 24-jährige Phillip fühlt seit einiger Zeit eine innere Leere. Im Studium fehlt ihm (German): die Kraft und Motivation, sich so anzustrengen, wie er es vor einem Jahr konnte. Selbst wenn er die Kraft dazu hätte, bereiten ihm Konzentrationsstörungen Schwierigkeiten. Hinzu kommen die Versagensängste, dass er in seinen jungen Jahren dem Studium nicht gewachsen ist und dieses nicht erfolgreich bewältigen kann. Auch zu Hause ist seine Stimmung oft gedrückt, sodass er eigentlich keine Lust hat, sich mit seinen Freunden zu treffen. Zusätzlich leidet er unter Schlafstörungen, was dazu führt, dass er oft sehr müde ist und den Alltag kaum aus eigener Kraft bewältigen kann.

Phillips Freunden ist Phillips gedrückte Stimmung bereits aufgefallen, aber sie versuchen trotzdem wiederholt, ihn zu einem Treffen zu überreden. Nachdem Phillip immer wieder ablehnt, fragen Phillips Freunde seltener nach ihm. Die Versuche, ihn weiterhin in Aktivitäten einzubinden, bleiben schließlich aus. $\mathrm{Zu}$ seiner Familie verringert sich nach und nach der Kontakt. Dadurch, dass Phillip sich nicht mehr bei ihnen meldet, bricht auch hier der Kontakt nach einiger Zeit vollständig ab. Phillip fühlt sich nach wie vor schlecht und denkt darüber nach, sein Studium in seinen jungen Jahren abzubrechen.

English 24-year-old Phillip has been feeling hollow for some time. He lacks the energy and Translation: motivation to try as hard as he used to be able to a year ago. Even if he could muster the energy, difficulties with concentration hinder him. On top of that is his fear of failure that he is not capable of doing his course even at his young age and that he cannot successfully get through it. Even at home, his mood is low, resulting in him not wanting to meet up with his friends. In addition, he has trouble sleeping, causing him to be tired a lot and frequently preventing him from managing everyday life on his own.

Phillip's friends have already become aware of his low mood. They have tried multiple times to motivate Phillip to participate in activities with them and to cheer him up. After Phillip repeatedly rejects, Phillip's friends ask for him less often. Attempts to keep him involved in activities eventually fail. Contact with his family gradually decreases. Because Phillip no longer contacts them, contact breaks off completely after some time. Phillip still feels bad and thinks about breaking off studies at his young age. 


\section{Stimulus 7}

Description: $\quad$ Exemplar depicting an older male student with social support.

Manipulations: Exemplar's Age: Old

Exemplar's Sex: Male

Story Ending: Social Support

Original Stimulus Der 56-jährige Franz fühlt seit einiger Zeit eine innere Leere. Im Studium fehlt ihm (German): die Kraft und Motivation, sich so anzustrengen, wie er es vor einem Jahr konnte. Selbst wenn er die Kraft dazu hätte, bereiten ihm Konzentrationsstörungen Schwierigkeiten. Hinzu kommen die Versagensängste, dass er in seinem hohen Alter dem Studium nicht gewachsen ist und dieses nicht erfolgreich bewältigen kann. Auch $\mathrm{zu}$ Hause ist seine Stimmung oft gedrückt, sodass er eigentlich keine Lust hat, sich mit seinen Freunden zu treffen. Zusätzlich leidet er unter Schlafstörungen, was dazu führt, dass er oft sehr müde ist und den Alltag kaum aus eigener Kraft bewältigen kann.

Franz' Freunden ist Franz gedrückte Stimmung bereits aufgefallen. Sie versuchen wiederholt, Franz zu gemeinsamen Aktivitäten zu motivieren und ihn aufzumuntern. Auch wenn es schwierig ist, lassen seine Freunde den Kontakt nicht abbrechen. Seine Familie kommt ihn regelmäßig besuchen und auch diese versucht, zusammen mit Franz etwas zu unternehmen, was ihm Spaß machen könnte. Zusätzlich telefoniert seine Familie täglich mit ihm, um zu sehen, wie es ihm geht. Aufgrund des sozialen Rückhalts fühlt sich Franz zeitweise besser und er kann sein Studium in seinem hohen Alter weiter fortsetzen.

English 56-year-old Franz has been feeling hollow for some time. He lacks the energy and Translation: motivation to try as hard as he used to be able to a year ago. Even if he could muster the energy, difficulties with concentration hinder him. On top of that is his fear of failure that he is not capable of doing his course at his older age and that he cannot successfully get through it. Even at home, his mood is low, resulting in him not wanting to meet up with his friends. In addition, he has trouble sleeping, causing him to be tired a lot and frequently preventing him from managing everyday life on his own.

Franz's friends have already become aware of his low mood. They have tried multiple times to motivate Franz to participate in activities with them and to cheer him up. Even though it is hard, his friends have not let contact break off between them. His family visits him regularly and they also try to do some activities together that might be fun for him. In addition, his family calls every day to see how he is doing. As a result of this social support, Franz feels better from time to time and can resume his studies. 


\section{Stimulus 8}

Description: $\quad$ Exemplar depicting an older male student without social support.

Manipulations: $\quad$ Exemplar's Age: Old

Exemplar's Sex: Male

Story Ending: No Social Support

Original Stimulus Der 56-jährige Franz fühlt seit einiger Zeit eine innere Leere. Im Studium fehlt ihm (German): die Kraft und Motivation, sich so anzustrengen, wie er es vor einem Jahr konnte. Selbst wenn er die Kraft dazu hätte, bereiten ihm Konzentrationsstörungen Schwierigkeiten. Hinzu kommen die Versagensängste, dass er in seinem hohen Alter dem Studium nicht gewachsen ist und dieses nicht erfolgreich bewältigen kann. Auch zu Hause ist seine Stimmung oft gedrückt, sodass er eigentlich keine Lust hat, sich mit seinen Freunden zu treffen. Zusätzlich leidet er unter Schlafstörungen, was dazu führt, dass er oft sehr müde ist und den Alltag kaum aus eigener Kraft bewältigen kann.

Franz' Freunden ist Franz' gedrückte Stimmung bereits aufgefallen, aber sie versuchen trotzdem wiederholt, ihn zu einem Treffen zu überreden. Nachdem Franz immer wieder ablehnt, fragen Franz' Freunde seltener nach ihm. Die Versuche, ihn weiterhin in Aktivitäten einzubinden, bleiben schließlich aus. $\mathrm{Zu}$ seiner Familie verringert sich nach und nach der Kontakt. Dadurch, dass Franz sich nicht mehr bei ihnen meldet, bricht auch hier der Kontakt nach einiger Zeit vollständig ab. Franz fühlt sich nach wie vor schlecht und denkt darüber nach, sein Studium in seinem hohen Alter abzubrechen.

English 56-year-old Franz has been feeling hollow for some time. He lacks the energy and Translation: motivation to try as hard as he used to be able to a year ago. Even if he could muster the energy, difficulties with concentration hinder him. On top of that is his fear of failure that he is not capable of doing his course at his older age and that he cannot successfully get through it. Even at home, his mood is low, resulting in him not wanting to meet up with his friends. In addition, he has trouble sleeping, causing him to be tired a lot and frequently preventing him from managing everyday life on his own.

Franz's friends have already become aware of his low mood. They have tried multiple times to motivate Franz to participate in activities with them and to cheer him up. After Franz repeatedly rejects, Franz's friends ask for him less often. Attempts to keep him involved in activities eventually fail. Contact with his family gradually decreases. Because Franz no longer contacts them, contact breaks off completely after some time. Franz still feels bad and thinks about breaking off studies at his older age. 